\title{
GLOBAL AND LOCAL CSR STRATEGIES IN FOREIGN-OWNED SUBSIDIARIES: THE ROLE OF NETWORKS AND COMPETENCIES
}

\author{
ESTRATEGIAS DE RSC GLOBALES Y LOCALES EN FILIALES DE PROPIEDAD \\ EXTRANJERA: EL PAPEL DE LAS REDES Y LAS COMPETENCIAS
}

\author{
Sven Dahms $s^{\mathrm{a}}$ \\ Classification: Empirical paper - research \\ Received: April 3, 2020 / Revised: June 6 \& July 17,2020 / Accepted: July 24, 2020
}

\begin{abstract}
The purpose of this research is to investigate the role of networks and competency dimensions in determining the corporate social responsibility (CSR) strategy of foreign-owned subsidiaries. Survey data has been collected from subsidiary managing directors and analysed using structured equation modelling and fuzzy set qualitative comparative analysis techniques. We show that networks and competencies can have competing as well as complementary effects on the global and local CSR strategies. For instance, inter-organisational network strength and competencies in high primary value chain activities seem to drive global as well as local CSR activities. However, the case is more complex for intra-organisational network relationships and subsidiaries with competencies in supporting value chain activities. The originality of this paper lies in the detailed investigation of how network relationships and competencies affect global and local CSR strategy development. We also provide novelty in applying a combination of symmetric (SEM-PLS) and non-symmetric (fsQCA) analytical techniques.
\end{abstract}

Keywords: Competence, corporate social responsibility, foreign-owned subsidiary, fsQCA, network.

\section{Resumen}

El propósito de este artículo es investigar el papel de las redes y las dimensiones de competencia en la determinación de la estrategia de responsabilidad social corporativa (RSC) de las subsidiarias de propiedad extranjera. Los datos de la encuesta se han recopilado de los directores generales de las subsidiarias y se han analizado utilizando modelos de ecuaciones estructuradas y técnicas de análisis comparativo cualitativo de conjuntos difusos. Demostramos que las redes y las competencias pueden tener efectos competitivos y complementarios en las estrategias de RSE globales y locales. Por ejemplo, la fuerza y las competencias de la red interorganizacional en las actividades de la cadena de valor primario alto parecen impulsar las actividades de RSE tanto a nivel mundial como local. Sin embargo, el caso es más complejo para las relaciones de redes dentro de la organización y las subsidiarias con competencias para respaldar las actividades de la cadena de valor. La originalidad de este artículo radica en la investigación detallada de cómo las relaciones y competencias de la red afectan el desarrollo de la estrategia de RSC global y local. También aportamos novedad en la aplicación de una combinación de técnicas analíticas simétricas (SEM-PLS) y no simétricas (fsQCA).

Palabras clave: competencia, responsabilidad social empresarial, subsidiaria de propiedad extranjera, fsQCA, red.

a College of Business and Public Management, Wenzhou Kean University, Ouhai District, Wenzhou, Zhejiang, China, E-mail: svendahms@ hotmail.com 


\section{Introduction}

The determination of corporate social responsibility (CSR) strategic focus in subsidiaries of multinational enterprises continues to puzzle academics and practitioners alike (Buckley, Doh \& Benischke, 2017; Jaén, Auletta, Celli, \& Pocaterra, 2018; Jamali \& Karam, 2016). On the one hand, there is a pronounced tension between global and local strategic foci that puts great strain on managers at the headquarters as well as at a subsidiary level (Husted \& Allen, 2006; Hah \& Freeman, 2014), while on the other hand, headquarter managers are concerned about the big picture, that is how the multinational wants to be perceived as a whole (Jamali, 2010). Additionally, there is a wide network of foreign-owned subsidiaries dispersed worldwide, each specialised in certain value adding activities, and exposed to very different host country environments (Campbell, Eden, \& Miller, 2012; Verbeke, Kano, \& Yuan 2016). This creates bounded rationality problems for headquarters (Rugman \& Verbeke, 2003), which in turn requires autonomous behaviour from the side of the subsidiary in order to assess the best ways to engage with CSR locally and globally in the context of the subsidiary. As such, CSR has been identified as a valuable strategic marketing tool with local and global implications (Park \& Ghauri, 2015; Yin \& Jamali, 2016); however, CSR strategic alignment is even more complicated for multinationals operating in emerging markets due to the relative novelty of CSR practises in such locations (Dahms, 2019a; Jamali \& Karam, 2016; Reimann, Ehrgott, Kaufmann, \& Carter 2012). This global and local CSR strategy nexus can have serious implications; for instance, there are plenty of examples where multinationals somewhat neglected the local aspects of CSR. This can be costly, as Taiwanese owned companies experienced in Vietnam in 2014 when they found themselves in the middle of riots over a political row between the Peoples Republic of China and Vietnam. The rioters mistook the Taiwanese firms for companies from the Peoples Republic of China, resulting in damaged factories and temporary closures (BBC, 2014).

This article aparts from adjacent studies by putting the limelight on networks and competencies as subsidiary characteristics rather than institutions or the integration-responsiveness framework, which are more commonly applied in the field (Frynas \& Yamahaki, 2016; Husted \& Allen, 2006). One the one hand, institutionalists propagate the influence of legitimacy and isomorphic pressures to predict subsidiary CSR strategy development (Benites-Lazaro \& Mello-Théry, 2017; Hah \&Freeman, 2014; Tatoglu, Bayraktar, Sahadev, Demirbag, \& Glaister, 2014), while others argue that such forces might be less pronounced than often assumed (Campbell et al., 2012; Jamali, 2010). For instance,
Japanese multinational enterprises show few signs of legitimacy seeking behaviour because of their confidence in home-grown technology, management practises and competencies (Gaur, Delios, \& Singh, 2007). Furthermore, Shirodkar, Beddewela, \& Richter (2016) found in their recent study no support for their proposed link between institutional distance and political CSR use by multinationals operating in India. In a related study, Reimann, Rauer, \& Kaufmann (2015) points towards the importance of internal factors such as subsidiary size to predict CSR commitment of foreign-owned subsidiaries. On the other hand, while the integration-responsiveness framework with its clear-cut typologies sounds appealing at first, it has difficulties in accommodating current international business realities. For instance, the finer slicing of value adding activities across an internationally dispersed network of subsidiaries very often does not allow for such a clear-cut typology (Rugman \& Verbeke, 2001; Verbeke et al., 2016).

In this article, we want to identify the previously rather neglected role that the characteristics of foreign-owned subsidiaries located in emerging markets play in the development of global and local CSR strategies. In order to do so, we ground our arguments in the competencebased view of the firm and the networks perspective. Those two perspectives are dominating current international business literature on the strategic development of foreign-owned subsidiaries (Gammelgaard, McDonald, Stephan, Tüselmann, \& Dörrenbächer, 2012; Verbeke et al., 2016). Competencies are embodied in value adding activities which are often internationally dispersed across the multinationals' networks, which are seen as key for multinational enterprises to sustain competitive advantages (Rugman \& Verbeke, 2001). We therefore believe that competencies and networks also play a crucial role in influencing CSR strategy of foreign-owned subsidiaries. The objective of this research is to provide new insights for our understanding of how competencies and network strength influence the global and local focus of CSR in foreign-owned subsidiaries. We further aim to understand potential competing and complementary configurations between those two perspectives. This objective we achieve by using configurational analysis to complement our symmetric structured equation model-based analysis. We employ fuzzy set qualitative comparative analysis to test for equifinality. Equifinality means that several different combinations of conditions can lead to the same desired outcomes. In our case, this allows us to identify subsidiaries that rely on a mix of conditions such as different competencies or networks in order to develop relevant CSR strategic foci. Such combinations of conditions are much harder to identify when traditional symmetric methods are exclusively used, where explanatory 
variables are considered to independently affect the outcome variable (Ragin, 2008; Woodside, 2013). In order to do so, we develop a conceptual framework and test our predictions on a sample of foreign-owned subsidiaries located in the mid-range emerging economy of Taiwan.

Taiwan experienced rapid development in the 1980s and 1990s driven by liberalisation of its domestic economy and preferential trade agreements with various countries including the USA. While for many countries in South America, the economic development trajectory was less steep, there are nevertheless lessons that can be learned. For instance, the share of the manufacturing sector contribution to GDP is around 30\% in Taiwan, a characteristic that it shares with Chile (Statista, 2020). But there are more similarities on the subnational level, for instance Sao Paolo in Brazil or Buenos Aires in Argentina show industrial structures similar to other global cities such as Taipei (Csomós, 2017).

We contribute to this novel field of research on a theoretical as well as a methodological level. First, by applying the competence-based view of the firm and network perspectives, we follow calls by Doh, Husted, Matten, and Santoro (2010) and Jamali (2010) for more research on multinational CSR activities which are grounded in international business theories. We also contribute to the discussions on the neglected internal factors, in our case subsidiary competencies, which influence CSR strategies (Frynas \& Yamahaki, 2016). Second, we analyse survey data from 101 subsidiaries from ten different home countries using symmetric and asymmetric methods to test for potential equifinality in our framework. This means, we argue that instead of having only symmetric associations between variables (as predominant in most studies, c.f. Prado \& Woodside, 2015) we suggest that there are multiple network and competence configurations that can lead to local or global CSR strategies in foreign-owned subsidiaries. We also contribute by focussing on foreign-owned subsidiaries located in Taiwan. CSR activities in emerging economies is seen as a field of growing interest because CSR patterns often differ from those found in fully developed market economies (Jamali \& Karam, 2016). There are also practical implications for managers. In particular, this research aims to develop guidelines regarding which configurations favour what kind of strategic CSR focus. This knowledge can reduce managerial processing time, which is a scarce resource in most firms.

\section{Literature Review and Hypothesis Development}

\section{Global and Local CSR Strategies in Foreign-Owned Subsidiaries}

Subsidiaries of multinational enterprises are caught up in two different worlds. On the one hand, they are considered part of one of the most powerful economic entities in the world and have therefore a global responsibility to internalise negative externalities (Sethi, 1990), while on the other hand, their subsidiaries are just like any other company embedded in the local economic networks and the global 'hype' can feel rather remote. This creates problems for managers in multinational enterprises because there might be a difference between globally accepted hypernorms and local expectations (Donaldson \& Dunfee, 1994). Such pressures might be even more accentuated in subsidiaries located in emerging economies since CSR is still a rather novel phenomenon in such locations (Jamali \& Karam, 2016).

However, there is no clear-cut distinction between global and local CSR in the literature. Therefore, we found it helpful to follow Husted and Allen's (2006) proposed classification since their article builds the foundation for numerous subsequent discussions (e.g. Jamali, 2010; Hah \& Freeman, 2014). Hence, global CSR issues relate to environmental and social causes. Environmental causes, such as the reduction of pollution within the global warming debate, or the continuing discussion of gender equality are issues that are recognised worldwide. By the term 'local', we refer to local community projects and job creation. While job creation and community projects are strong pull factors for host locations worldwide to attract investment from multinational enterprises, it is seen herein as a CSR issue with a localised impact.

Although the topic of global and local CSR in foreign-owned subsidiaries has attracted considerable attention, there remain a number of unknowns on the conceptual as well as empirical level. Conceptually, with a few exceptions (e.g. Reimann et al., 2015), most studies focus exclusively on the institutional side and neglect the internal business side of the argument (Frynas \& Yamahaki, 2016; Jamali, 2010). For instance, according to the institutional perspective, multinationals show a strong focus on local stakeholders and their practises in order to achieve legitimacy in the host country through isomorphism (Rathert, 2016; Reimann et al., 2012; Yang \& Rivers, 2009). While we do not dismiss the existence of such institutional pressures, we believe that other forces also play a role here. We argue that the local and global CSR focus is also determined by internal considerations in our context subsidiary characteristics. For instance, Frynas \& Yamahaki (2016) argue in their comprehensive review that the majority of studies have so far focused on the external factors such as stakeholders and institutional pressures only, but neglected the internal ones, such as competencies that drive CSR strategies in multinational enterprises. Other studies also indicated that multinationals which struggle with institutional pressures 
in host countries are likely to focus predominantly on the home country business practises rather than localisation and isomorphism (Campbell et al., 2012; Gaur et al., 2007).

Therefore, we argue that the cost of focusing on global or local CSR strategies depends much more on network strength and the competence level of the subsidiary rather than on institutional differences between home and host countries. In other words, the multinational enterprise's decision process that determines how to internationally distribute value adding activities in order to develop specific competencies, which embed those in the intraand inter-organisational networks, defines the CSR strategy, rather than institutional considerations alone.

Furthermore, there is a dearth of empirical studies in the field which focus on subsidiary characteristics in emerging markets (Jamali \& Karam, 2016) and much of the discussion has taken place in the conceptual realm (e.g. Hah \& Freeman, 2014; Yang \& Rivers, 2009) or is based on case study evidence (e.g. Jamali, 2010; Muller, 2006). Furthermore, only a few studies focus on emerging economies (Husted \& Allen, 2006), while others focus only on particular CSR practises (e.g. Shirodkar et al., 2016; Tatoglu et al., 2014) or CSR commitment (Reimann et al., 2015), but neglect the global versus local strategic CSR nexus.

\section{Network Relationship Strengths and Subsidiary CSR Focus}

The multinational enterprise is seen today as a differentiated network of headquarters and subsidiaries (Ghoshal $\&$ Bartlett, 1990) in which each entity carries out different parts of the value chain (Rugman \& Verbeke, 2001). In this study we distinguish between intra-organisational networks (e.g. internal suppliers, buyers, R\&D centres, and headquarters) and inter-organisational networks (external buyers, suppliers, competitors, governmental institutions, universities) (Gammelgaard et al., 2012). Each network can have a different effect on how the subsidiary's CSR strategy develops.

Intra-organisational networks play an important role in the knowledge exchange within the multinational (Ghoshal \& Bartlett, 1990). Stronger integration can also indicate a mutual dependency of the subsidiary with the rest of the multinational and vice versa (Gammelgaard et al., 2012; Monteiro, Arvidsson, \& Birkinshaw, 2008). Strong intra-organisational network relationships are therefore likely to indicate an internal strategic focus of the subsidiary (Bouquet \& Birkinshaw, 2008; Yin \& Jamali, 2016). Park \& Ghauri (2015) found in an adjacent study of Korean MNE subsidiaries that internal managers can have a strong impact on CSR practises. Such orientation towards the development of intra-organisational relationships might therefore foster a global CSR strategy aligned with other parts of the multinational enterprise. As a result, local CSR strategy might be neglected. Hence, our first hypotheses:

Hypothesis 1: There is a positive association between intra-organisational network strength and (global and local) CSR strategy.

Inter-organisational relationships are often seen as a key when it comes to accessing location specific advantages such as intangible knowledge found in local supplier or buyer networks (Andersson, Forsgren, \& Holm, 2002; Ghoshal \& Bartlett, 1990). Such network relationships require the development of strong ties to facilitate knowledge transfer (Gammelgaard et al., 2012). Access to such location specific networks is often driven by two cost factors for the subsidiaries. First, the management resources that need to be employed in order to develop such stronger and transaction cost minimising networks (Rugman \& D'Cruz, 2003). Second, an increased uncertainty caused by a lack of knowledge of local business practises and potential active discrimination against foreign companies in host countries (Shapiro, Vecino, \& Li, 2018; Zaheer, 1995). Shirodkar et al., (2016) showed that if inter-organisational relationships become crucial for subsidiary survival in India, it is more likely to engage in political corporate social responsibility. We therefore believe that strong inter-organisational networks lead to a local CSR focus in the subsidiary.

In addition, foreign-owned subsidiaries located in emerging economies might be also in the spotlight for geopolitical reasons (Hah \& Freeman, 2014). In combination with the potential importance of accessing local inter-organisational networks for the subsidiary, as well as the multinational as a whole, it might well be that this also drives a pronounced adherence to global CSR strategy agenda (Jamali, 2010; Park \& Ghauri, 2015). It would hence be expected that subsidiaries with strong inter-organisational network relationships also show a strategic focus on global CSR. This leads to our second set of hypotheses:

Hypothesis 2: There is a positive association between inter-organisational network strength and (global and local) CSR strategy.

\section{Competencies and CSR Focus}

The competence-based view of the firm argues that firms sustain their competitiveness through the development of 
relative knowledge advantages (Dahms, 2019b, 2019c; Hamel \& Prahalad, 1996). Those competencies are, in the case of multinational enterprises, globally dispersed in the form of value adding activities (Verbeke et al., 2016). Frynas \& Yamahaki (2016) argue that the competencies of multinationals are often neglected in the literature on CSR strategy. We argue that competencies in value adding activities drive the development of CSR strategies in foreign-owned subsidiaries. Jamali (2010) showed some indicative evidence for our claim. Her study found that some subsidiaries link their CSR activities with their core competencies. For instance, a company that excels in technology development might engage in CSR activities that involve information technology. In the light of those arguments, we distinguish herein competencies embedded in primary and supporting value adding activities. This is a useful distinction because it allows us to get a better idea about the finely sliced value adding activities distributed within the international network of the multinational (Rugman \& Verbeke, 2001). It also goes beyond adjacent CSR studies that approximated subsidiary competencies by subsidiary size only (e.g. Reimann et al., 2015).

In particular, primary competencies are associated with value chain activities such as production, sales, or logistic activities (Porter, 1985). Those activities are more likely to be found in subsidiaries that show lower levels of relatively high-skilled labour, and in foot-loose investments commonly encountered in emerging markets (Delany, 2000). Because of their more labour-intensive nature, such as in production, this might be conducive to a local CSR strategy. At the same time, other primary functions, such as sales, which can also have a strong international component to it (Nguyen \& Rugman, 2015), might also require a global strategic focus in CSR. Hence, we expect that primary competencies are conducive to the development of a local as well as global CSR strategy in foreign-owned subsidiaries.

Hypothesis 3: There is a strong positive association between primary competencies and (global and local) CSR focus.

Supporting competencies are associated with activities such as purchasing, research and development or other higher order administrative activities such as law or accounting (Porter, 1985). Those activities are less frequently found in foreign-owned subsidiaries due to their higher fixed costs and the required greater local commitment (Moore, 2001). As such we expect those competencies to have only a weak association with the local CSR strategy. For instance, the staff composition of subsidiaries with research and development value chain activities is likely to be more internationally diverse rather than those from a particular locality only (Sapouna, Manolopoulos, \& Dimitratos, 2016). This might imply that the subsidiary relies to a lesser extent on the local workforce, which in turn, might make the reduced cost of transaction in the hiring process through localised CSR strategies less attractive for subsidiary managers (Albinger \& Freeman, 2000; Yin \& Jamali, 2016).

Furthermore, because of the high value adding nature of those activities and the prestige that comes with hosting such activities within the multinational (Bouquet \& Birkinshaw, 2008), such competences might also have only a weak global CSR association. Additionally, underlying such supporting activities is a relatively high cost structure, which might reduce the managerial resources that can be committed to CSR strategies as a whole (Yin \& Jamali, 2016). Hence, our fourth hypothesis is as follows:

Hypothesis 4: There is a weak positive association between support competencies and (global and local) CSR focus.

\section{Equifinality and CSR Strategy}

We have so far advocated a symmetric perspective on the associations between subsidiary networks and CSR strategy as well as subsidiary competencies and CSR strategy. However, given the lack of empirical studies and the ongoing conceptual discussions, we believe that there might also be ground for the possible existence of a combination of network and competence factors that lead to global or local CSR strategies in foreign-owned subsidiaries. Similar to the field of organisational performance (e.g. Fiss, 2007; Dahms \& Kingkaew, 2019), CSR is a multidimensional concept that might be influenced by several factors simultaneously (Amini \& Dal Bianco, 2017; Prado \&

\section{Figure 1. Conceptual Framework}

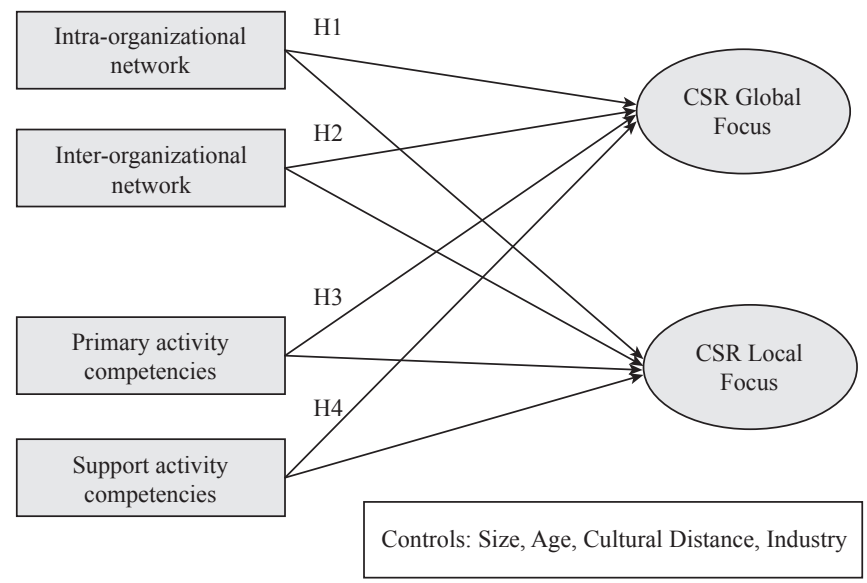


Woodside, 2015). In other words, while we acknowledge that competencies and networks might have competing influences, we should not rule out a potential complementarity between those two perspectives.

We therefore believe that there are likely combinations of network and competence conditions that influence the subsidiary management in focussing on a global or a local CSR strategy. For instance, Jamali (2010) found that some subsidiaries associate their CSR strategy with competencies; however, this might simultaneously also depend on their organisational network strengths. It is thinkable, for example, that inter-organisational relationship strength might be more important for subsidiaries that have concurrently high primary competencies, which in turn favour a strong local CSR strategy. Accordingly, our last hypothesis is as follows:

Hypothesis 5: Differing combinations of networks and competencies can lead to global and local CSR strategies.

\section{Research Method}

\section{Context}

We analysed foreign-owned subsidiaries located in Taiwan. Taiwan offers an interesting research context as a mid-range emerging economy (Hoskisson, Wright, Filatotchev, \& Peng, 2013), which is located next to the much larger economies of China and Japan. Mid-range means that it has many of the institutional, factor market and infrastructure characteristics of developed economies, but still falls short in some aspects such as judiciary speed or education. It therefore provides ideal grounds to investigate more recent phenomena such as CSR strategies. Taiwan also has a relatively long history of foreign-direct investment (US State Department, 2013), which means that many multinationals are well acquainted with the country's conditions.

\section{Data Collection \& Sample}

The sample universe is based on a Dun \& Bradstreet database of all subsidiaries in Taiwan with at least $50 \%$ foreign ownership stake. Dun \& Bradstreet database is commonly used for that purpose in subsidiary development research (e.g. Gammelgaard et al., 2012). We designed the data collection method along the lines of the world enterprise surveys carried out by the World Bank (World Bank, 2011). It is an international survey conducted in many emerging economies in which research is less common; hence, personal contact is seen as the key to increasing response rates. Accordingly, a call centre had been established at the university. The call centre agents had been trained for 9 hours prior to conducting the survey. The managing directors of the subsidiaries have been contacted because they are most likely to have the information and knowledge required to answer our survey (John \& Weitz, 1988; Reimann et al., 2015). After several attempts to contact the companies over the time period between March and May 2017 we achieved a net response rate of $22 \%$ (101 out of 458 ), which is in line with adjacent studies (e.g. Kingkaew \& Dahms, 2018; Reimann et al., 2015; Shirodkar et al., 2016).

The respondents have headquarters in ten different home countries, with the majority in the United States and Japan. Further sample characteristics are presented in table 1 . We found that the majority of subsidiaries are over 21 years old and hence rather well established for an emerging economy. The majority is comparatively small with the largest frequency in the 11-30 employees' group. The preferred mode of entry is Greenfield investment and the majority are operating in the service sector.

We conducted t-tests for non-response bias according to industry, size, and home country. The results showed no evidence of non-response bias in our sample.

\section{Survey Instrument}

Before conducting the survey, the questionnaire has been pilot tested in three face-to-face assessment sessions with managing directors from different industries and countries. This resulted in minor wording changes. Afterwards, the questionnaire has been forward and back ward translated with the help of Chinese speaking academics and practitioners in Taiwan as well as the United Kingdom.

Table 1. Sample Characteristics

\begin{tabular}{|c|c|c|c|c|c|}
\hline \multicolumn{3}{|c|}{ Size (number of employees) } & \multicolumn{3}{|c|}{ Years in foreign ownership } \\
\hline Employees & Freq. & $\%$ & Years in FO & Freq. & $\%$ \\
\hline$<10$ & 34 & 34 & $<10$ years & 25 & 25 \\
\hline $11-30$ & 36 & 36 & 11-20 years & 35 & 35 \\
\hline$>31$ & 31 & 30 & $>21$ years & 41 & 40 \\
\hline Total & 101 & 100 & Total & 101 & 100 \\
\hline \multicolumn{3}{|c|}{ Entry mode } & \multicolumn{3}{|c|}{ Industry } \\
\hline & Freq. & $\%$ & & Freq. & $\%$ \\
\hline Greenfield & 67 & 66 & Manufacturing & 44 & 44 \\
\hline Acquisition & 11 & 11 & Service & 57 & 56 \\
\hline Joint Venture & 23 & 23 & Total & 101 & 100 \\
\hline Total & 101 & 100 & & & \\
\hline
\end{tabular}


We adapted existing scales from Husted \& Allen (2006) to measure the global and local CSR strategy. In particular, we asked the managers to "Asses how important the following issues are for the subsidiaries' business mission:" on a Likert-Scale from (1) not important to (7) very important. The issues covered were for local strategic focus: the job creation and community projects, for the global strategy: environment and social causes. The complete constructs can be found in table 2 .

Subsidiary primary and supporting competencies are based on Birkinshaw, Hood, \& Jonsson, (1998) and Verbeke et al., (2016). In particular, we distinguish between primary activity competencies (sales/marketing, production of goods or services, logistics/distribution) and supporting activities competencies [research \& development, human resource management, other administrative functions (e.g. legal, financial, etc.), purchasing]. The interand intra-organisational network relationship strength has been measured following the studies of Gammelgaard et al., (2012) and Dahms (2018). Participants were asked to indicate the strength of relationships $(1=$ very weak, $7=$ very strong). Intra-organisational actors: buyers within the corporation, suppliers within the corporation, $\mathrm{R} \& \mathrm{D}$ and innovation centres within the corporation, headquarters, other units within the corporation. Inter-organisational actors included governmental institutions in Taiwan, science centres, universities in Taiwan, local suppliers, buyers and competitors

\section{Control Variables}

We also included control variables in our models. We included the age of the establishment as the number of years since the subsidiary is under foreign ownership in order to control for experience curve effects (Birkinshaw et al., 1998). Size, as the number of employees at the site, has been included given that it can be an indicator for subsidiary influence within the MNE network (Bouquet \& Birkinshaw, 2008) as well as resources (Reimann et al., 2015). We also control for industry since service and manufacturing sector affiliation can affect subsidiary development (Gammelgaard et al., 2012). We coded manufacturing as 0 and service as 1 . Lastly, we controlled for cultural distance between home and host country because informal institutional differences can influence subsidiary development. We based our measure on Hofstede's cultural dimensions and calculated the distance between home and host country using the Kogut \& Singh (1988) formula.

\section{Common Method Bias}

We undertook a number of steps to reduce potential common method bias. Ex ante, we randomly distributed our constructs in the questionnaire, which makes it hard for the respondent to guess our intentions. This is further underpinned by the use of complex analytical methods employed in this study. We also ensured confidentiality of the responses to the managers. Ex post, in line with Shirodkar et al., (2016), we conducted a Harman's one factor test, which resulted in a total variance explained of well below the threshold of $50 \%$ for the largest factor (Podsakoff \& Organ, 1986). Furthermore, the variance inflation factors are all below the commonly applied threshold of 5 (Hair, Sarstedt, Pieper, \& Ringle, 2012). Hence, common method bias is not deemed a threat to the interpretation of our results.

\section{Results}

We use structural equation modelling - partial least squared (SEM-PLS) for our symmetric hypothesis and fuzzy set qualitative comparative analysis (fsQCA) technique for the asymmetric hypothesis. For our analysis we used Warppls 5.0 software for SEM-PLS and fs/QCA 2.5 software for the fsQCA part.

\section{Symmetric Results and Model Assessments}

The measurement model assesses the reliability and validity of the measurement constructs. The factor loadings of each set of latent variables, as shown in table 2, range from 0.669 to 0.898 . The Composite reliabilities and Cronbach alpha values are above the 0.7 threshold. Hence, our model shows acceptable convergent validity (Fornell \& Larcker, 1981; Nunnally, 1978).

The square root of the average variance extracted is assessed for the discriminant validity and should be higher than the bivariate correlations between the latent variables (Fornell \& Larcker, 1981). The values in table 3 all adhere to this requirement. Furthermore, the variance inflation factors are well below the threshold of 5 (Hair et al., 2012) and the bivariate correlations are below the 0.8 threshold (Neter, Wasserman, \& Kutner, 1985), both of which indicate that multicollinearity is not a major issue for this study.

The results of the structural model are presented in table 4. Given the sample size, a stable method has been used to establish statistical significance of the paths (Kock, 2011). A stable method is different from simple bootstrapping in that it does not rely on the replication of samples alone and produces more stable path coefficients (Kock, 2014).

The R-squared values for the dependent latent variables were 0.28 for the local as well as for the global CSR strategy. We expected and confirmed a positive association between intra-organisational network strength and a 
Table 2. The Measurement Model

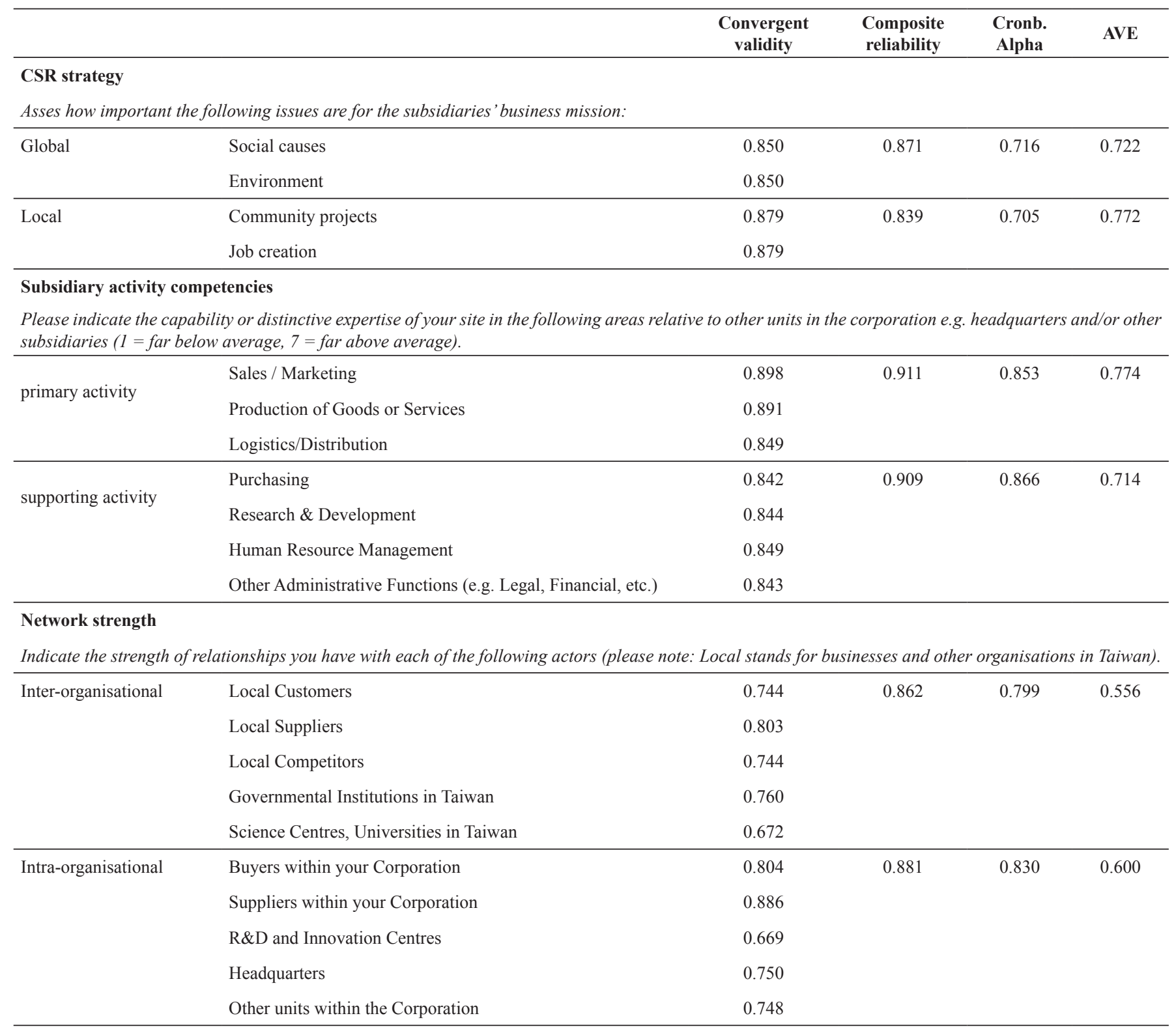

global CSR strategy (H1), but it was not significant for local CSR strategies. We predicted and confirmed that inter-organisational network strength would show a positive association with global and local (H2) CSR strategic foci. We also found a strong positive association between primary competencies and (global and local) CSR focus (H3). However, we found no statistically significant association between support activities and CSR strategies.

The overall model results are in line with previous studies and well within the range of generally accepted benchmarks for model fit (Kock, 2011). For instance, the inclusive goodness of fit measure, an indicator for overall model fit, is with 0.379 between medium and large (Wetzels, Odekerken-Schröder, \& Van Oppen, 2009). Q-squared values of the predicted variables reach from
0.292 to 0.325 , which indicates good predictive validity of the model (Kock, 2014). Complete model statistics are available from the author on request.

In terms of control variables, it should be noted that cultural distance was not significantly associated with either local or global CSR strategies. Age and size showed a positive and significant association with local CSR strategy. Industry was negative and significantly associated with local and global strategies.

\section{Asymmetric Results and Model Assessments}

fsQCA allows for asymmetric relationships between variables and for multiple combinations of conditions that can lead to the same outcome, i.e. equifinality (Fiss, 2007; Prado \& Woodside, 2015; Ragin, 2008). fsQCA 
Table 3. Discriminant Validity and Descriptive Statistics

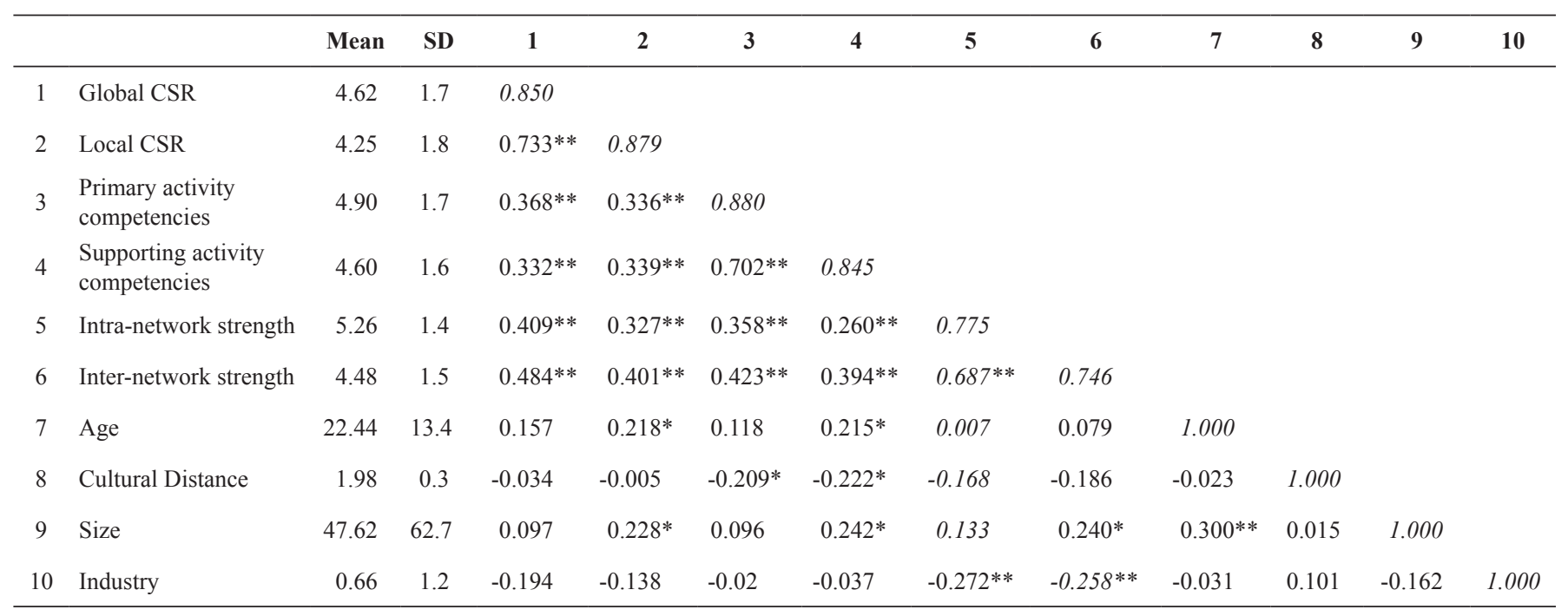

Note: Diagonals in italic are the square roots of the average variance extracted and off-diagonal are the bivariate correlations between the constructs. **. Correlation is significant at the 0.01 level (2-tailed). *. Correlation is significant at the 0.05 level (2-tailed).

is based on Boolean algebra and therefore uses a set theoretic approach. Accordingly, in order to establish set membership, the variables need to be calibrated. In other words, a variable needs to be transformed into a condition. Each condition represents a value that indicates if a condition is present in a certain outcome or not (Dahms, 2017a; Ragin, 2008; Schneider \& Wagemann, 2010).

Hence, the first step is to calibrate the data into fuzzy sets. This means we distinguish cases that are either fully in, fully out, or in between certain sets. We divide our values in 25 percentiles in which the $25^{\text {th }}$ is fully out $=0$, the $50^{\text {th }}$ percentile is the 0.5 cut-off point, and the $75^{\text {th }}$ percentile is $1=$ full membership.

Table 4. PLS-results

\begin{tabular}{lccc}
\hline \multicolumn{1}{c}{ Hypothesis/association } & $\begin{array}{c}\text { Path } \\
\text { coefficient }\end{array}$ & P-Value & $\begin{array}{c}\text { Hypothesis } \\
\text { supported }\end{array}$ \\
\hline H1: Intra-organisational networks & & & \\
\hline Global CSR & 0.137 & 0.079 & Yes \\
Local CSR & 0.060 & 0.271 & No \\
\hline H2: Inter-organisational networks & & & \\
\hline Global CSR & 0.259 & 0.003 & Yes \\
Local CSR & 0.175 & 0.034 & Yes \\
\hline H3: Primary activity competencies & & & \\
\hline Global CSR & 0.159 & 0.049 & Yes \\
Local CSR & 0.173 & 0.035 & Yes \\
\hline H4: Support activity competencies & & & \\
\hline Global CSR & 0.029 & 0.383 & No \\
Local CSR & 0.084 & 0.196 & No \\
\hline
\end{tabular}

Necessary condition analysis is presented in table 5 . None of the conditions reaches a consistency value of $>0.9$, which indicates that none of the conditions are necessary (Ragin, 2008). This implies that there is no single condition which by itself is necessary to predict global or local CSR strategies in foreign-owned subsidiaries.

Table 6 shows the intermediate solutions from the fsQCA in order to identify sufficient conditions. Solution coverage and consistency values are well within the range of usual thresholds (Ragin, 2008). As expected, we identify a pattern of equifinality in our solutions. This means that there are a number of configurations that can cause global or local CSR strategies. The most interesting solutions are the ones with the highest raw coverage.

Table 5. Analysis of Necessary Conditions

\begin{tabular}{|c|c|c|c|c|}
\hline \multirow[b]{2}{*}{ Conditions } & \multicolumn{2}{|c|}{ Global CSR } & \multicolumn{2}{|c|}{ Local CSR } \\
\hline & Consistency & Coverage & Consistency & Coverage \\
\hline $\begin{array}{l}\text { Supporting activity } \\
\text { competencies }\end{array}$ & 0.616 & 0.640 & 0.604 & 0.751 \\
\hline $\begin{array}{l}\sim \text { Supporting activity } \\
\text { competencies }\end{array}$ & 0.445 & 0.424 & 0.496 & 0.566 \\
\hline $\begin{array}{l}\text { Primary activity } \\
\text { competencies }\end{array}$ & 0.663 & 0.647 & 0.633 & 0.740 \\
\hline $\begin{array}{l}\sim \text { Primary activity } \\
\text { competencies }\end{array}$ & 0.403 & 0.408 & 0.462 & 0.559 \\
\hline Intra-network strength & 0.661 & 0.682 & 0.574 & 0.709 \\
\hline Intra-network strength & 0.414 & 0.396 & 0.507 & 0.582 \\
\hline Inter-network strength & 0.701 & 0.693 & 0.642 & 0.761 \\
\hline Inter-network strength & 0.361 & 0.360 & 0.450 & 0.538 \\
\hline
\end{tabular}

Note: the highest values are shown in bold, none was >0.9." " stands for "not". 
Coverage in fsQCA can be seen as the equivalent to the "R" value in traditional regression models. A solid circle $(\bullet)$ indicates the condition is present and $\otimes$ indicates its absence; a blank space indicates that the condition has no influence on the outcome (i.e. do not care). We also present the results for low local and global CSR strategies. This is because the presence of a condition for a high outcome does not automatically mean that its absence leads to a negated outcome (Schneider \& Wagemann, 2010).

Solution 1, for instance, indicates that high inter- and intra-organisational network strength as well as high supporting activity competencies lead to a global CSR strategy. Low global CSR strategy in solution 2, on the other hand, is caused by a lack of network strengths and the absence of primary activity competencies. This shows that the conditions for high and low global CSR strategic focus are different. Overall, the fsQCA results extend the symmetric findings in that networks and competencies can contribute to a global CSR strategic focus in a complementary way.

For local CSR strategies, we focus on solutions 3 and 4 , with the highest raw coverage. Solution 3 suggests that high local CSR focus is caused by strong inter-organisational network relationships and high supporting activity competencies. Solution 4 suggests that high primary and supporting competencies also lead to local CSR strategy. This expands the symmetric model findings by showing that higher supporting competencies in combination with strong local network relationships lead to a local CSR strategy focus. Contrary to that, the result of solution 7 also confirmed that in the absence of networks and primary competencies, strong supporting competencies lead to low local CSR strategy. However, this solution only accounts for a relatively small number of cases.

Overall, the fsQCA results confirm that there are different configurations from the network perspective as well as the competencies-based view of the firm that determine CSR strategies in foreign-owned subsidiaries located in emerging economies. Hence, we also confirm hypothesis 5 . The implications will be discussed next.

\section{Discussion and Conclusion}

The motivation behind this research was to investigate how networks and competencies affect the CSR strategy of foreign-owned subsidiaries located in an emerging economy. Based on the competence-based view of the firm and network perspectives, we analysed, using symmetric and asymmetric methods, how different kinds networks and competencies affect local and global CSR strategies of foreign-owned subsidiaries located in Taiwan.

We found that intra-organisational network strength shows a positive association with global CSR strategy, but no statistical association with local CSR strategies. This finding expands on related studies such as Park \& Ghauri (2015) and Yin \& Jamali (2016) in indicating that a strong intra-organisational network shifts the focus of subsidiary CSR strategy towards global and multinational enterprise network focussed CSR issues. This degree of network strength and CSR strategy trade-off has so far rarely been explicitly assessed in previous studies. However, Bouquet \& Birkinshaw (2008), for instance, have indicated that resource dependencies and network embeddedness can play a role in MNE internal power

Table 6. fsQCA Results

\begin{tabular}{|c|c|c|c|c|c|c|c|}
\hline \multirow[b]{2}{*}{ Condition $\quad$ Solution } & \multirow{2}{*}{$\begin{array}{c}\text { High Global CSR } \\
\text { strategy }\end{array}$} & \multirow{2}{*}{$\begin{array}{c}\text { Low Global CSR } \\
\text { strategy }\end{array}$} & \multicolumn{4}{|c|}{ High Local CSR strategy } & \multirow{2}{*}{$\begin{array}{c}\begin{array}{c}\text { Low Local CSR } \\
\text { strategy }\end{array} \\
7\end{array}$} \\
\hline & & & 3 & 4 & 5 & 6 & \\
\hline Primary activity competencies & & $\otimes$ & & - & $\otimes$ & - & $\otimes$ \\
\hline Supporting activity competencies & $\bullet$ & & $\bullet$ & $\bullet$ & & & $\bullet$ \\
\hline Intra-network strength & - & $\otimes$ & & & $\otimes$ & $\bullet$ & $\otimes$ \\
\hline Inter-network strength & $\bullet$ & $\otimes$ & - & & $\bullet$ & $\otimes$ & $\otimes$ \\
\hline Consistency & 0.826 & 0.831 & 0.833 & 0.792 & 0.787 & 0.702 & 0.780 \\
\hline Raw coverage & 0.407 & 0.473 & 0.469 & 0.537 & 0.159 & 0.130 & 0.181 \\
\hline Unique coverage & 0.407 & 0.473 & 0.018 & 0.077 & 0.051 & 0.014 & 0.181 \\
\hline Solution consistency & 0.826 & 0.831 & & & & & 0.780 \\
\hline Solution coverage & 0.407 & 0.473 & & & & & 0.181 \\
\hline frequency cut-off & 1.000 & 1.000 & & & & & 1.000 \\
\hline consistency cut-off & 0.816 & 0.806 & & & & & 0.780 \\
\hline
\end{tabular}


struggles within the multinationals network. A notion also found in the political CSR study of Shirodkar et al. (2016). In line with their assertion, our results indicate that CSR strategies are perhaps also affected by such internal power struggles and subsequent resource dependencies played out in intra-organisational network relationships.

We also found that strong inter-organisational networks are positively associated with global as well as local CSR strategy. This finding adds to studies that include local network effects on CSR strategy. For instance, we expand on Shirodkar et al. (2016) who did not find a link between business ties and political CSR activities in subsidiaries. Our study indicates that inter-organisational network strength might only affect certain kinds of CSR strategies. Our finding also somewhat contrasts with Husted \& Allen (2006) who suggested that strategic typologies with strong local foci are more prone to developing a local CSR strategy. We show that, due to their international exposure in emerging markets, subsidiaries can also develop a strategy that caters to local as well as global CSR foci.

Furthermore, we show that if the subsidiary has competencies in primary activities such as sales or production, it shows high commitment to local as well as global CSR strategies (H3). This indicates for subsidiaries with competencies in value chain activities that are more commonly associated with emerging markets such as sales or production (Delany, 2000); to show a strategic outlook that simultaneously caters to global as well as local CSR. This is in line with studies such as Shirodkar et al. (2016) or Reimann et al. (2015) who argue that larger subsidiaries are likely to have a competence advantage that allows showing a greater CSR commitment. However, we expand on their findings. We argue that instead of size, it is the nature of the competencies within the subsidiary that matter. This is also confirmed in the results for our final symmetric hypothesis, in which we found that high supporting activity competencies was not significantly associated with local and global CSR strategies (H4). This is an interesting finding because supporting value chain activities such as research and development or purchasing require greater investments and hence a stronger local commitment (Moore, 2001). At the same time, our results indicate that such subsidiaries show neither a global nor a local strategic CSR focus. We argue that this is the case because of their elevated position within the multinational, as well as the international staffing structure inside the subsidiary, and perhaps the lack of managerial resources that can be committed to CSR strategies.

We also add a novel twist to current debates in the literature by testing for equifinality through the use of fsQCA method (Fiss, 2007, Dahms, Cabrilo, \& Kingkaew, 2020). The goal was to look beyond the symmetric associations tested above and in most of the previous studies (for an exception see Prado \& Woodside, 2015). The fsQCA results showed that intra- and inter-organisational networks can indeed complement competencies to determine subsidiary CSR strategy. For instance, subsidiaries with strong intra- and inter-organisational networks as well as high support activity competencies show a focus on global CSR strategies. This extends our symmetric findings that suggested that an internal focus of subsidiaries is more likely to lead to a global CSR strategy. We also found that a local CSR strategy shows a complex pattern in that, for instance, high primary and supporting activity competencies are showing a high degree of local CSR focus. The other path to a local CSR strategy was found in subsidiaries with high support activity competencies and strong inter-organisational network strength. This perhaps indicates that for the majority of cases the advantages of local CSR strategies are worthwhile to invest management resources, which is in line with other studies such as Reimann et al. (2015). At the same time, the fsQCA confirmed that, although only in a relatively small number of cases, supporting activity competencies do foster a neglect of local CSR strategy. This is interesting since it might indicate that the most desired kind of foreign direct investment, which is for emerging market subsidiaries that develop higher value adding activities, can actually lead to a neglect of local CSR.

Our study also contributes with novel insights to ongoing discussions in the field. For instance, we show that the competence-based view of the firm, as well as the network perspective, can provide important understandings of how subsidiaries develop their local or global CSR strategies. This is in line with recent calls from Doh et al. (2010) and Jamali (2010) to incorporate insights from mainstream international business literature to explain CSR phenomena that are more commonly investigated using institutional theory. Furthermore, by applying SEM-PLS as well as fsQCA, we also contribute by showing that those two theoretical concepts provide competing as well as complementary explanations on how CSR strategy develops. This also complements the findings of Frynas and Yamahaki's (2016) review in showing that internal and external factors play a simultaneous role in CSR strategy. Our data analytical approach is also in line with trends in the broader management literature (Fiss, 2007) as well as the more specific CSR literature (Prado \& Woodside, 2015) to incorporate symmetric as well as asymmetric methods to test and expand conceptual frameworks in a rigorous manner. 


\section{Managerial and Policy Implications}

We also derive managerial and policy implications from our findings. Managers of foreign-owned subsidiaries ought to take into consideration its competencies as well as the internal and external networks in which it is integrated to decide on CSR strategies. For instance, although supporting activity competencies might at first appear to require less CSR focus, we found this only for a few cases to be true. If such competencies are embedded in local networks, then a local CSR strategy seems applicable. Policy makers might have an opportunity to support subsidiaries in their CSR strategic development. For instance, policy makers can set up foreign direct investment after care programs that could guide subsidiary managers on local CSR strategies if it becomes apparent that the subsidiary relies to a large extent on local networks for competence development.

\section{Limitations and Future Research}

As is the case with every study, ours too has limitations, which might lead to interesting future research. Firstly, our sample is confined to foreign-owned subsidiaries located in the mid-range merging economy of Taiwan. Other studies might further explore if our findings also hold in countries that follow a different development path. Second, we follow Husted and Allen (2006) for the design of our local and global CSR strategy measure. It might well be that there are other aspects that multinationals consider as local or global CSR and hence a more comprehensive measurement instrument might provide more detailed results. Moreover, while our sample size is in line with previous studies (e.g. Dahms, 2017b; Shirodkar et al. 2016), we do acknowledge that a larger sample size could bring new insights, especially towards a more extensive inclusion of control factors. Lastly, valuable insights could be gained from longitudinal studies (Chung \& Dahms, 2018) that show the evolution of CSR strategies in subsidiaries.

\section{References}

Albinger, H. S., \& Freeman, S. J. (2000). Corporate social performance and attractiveness as an employer to different job seeking populations. Journal of Business Ethics, 28(3), 243-253.

Andersson, U., Forsgren, M., \& Holm, U. (2002). The strategic impact of external networks: Subsidiary performance and competence development in the multinational corporation. Strategic Management Journal, 23(11), 979-996.
Amini, C., \& Dal Bianco, S. (2017). Corporate social responsibility and Latin American firm performance. Corporate Governance, 17(3), pp. 403-445.

BBC. (2014). Vietnam-China tensions: One dead in Taiwan mill protest. http://www.bbc.com/news/worldasia-27420008 (accessed 16 june 2017)

Benites-Lazaro, L. L., \& Mello-Théry, N. A. (2017). CSR as a legitimatizing tool in carbon market: Evidence from Latin America's clean development mechanism. Journal of Cleaner Production, 149, 218-226.

Birkinshaw, J., Hood, N., \& Jonsson, S. (1998). Building firm-specific advantages in multinational corporations: The role of subsidiary initiative. Strategic Management Journal, 19(2), 221-241.

Bouquet, C., \& Birkinshaw, J. (2008). Weight versus voice: How foreign subsidiaries gain attention from corporate headquarters. Academy of Management Journal, 51(3), 577-601.

Buckley, P. J., Doh, J. P., \& Benischke, M. H. (2017). Towards a renaissance in international business research? Big questions, grand challenges, and the future of IB scholarship. Journal of International Business Studies, 48(9), 1045-1064.

Campbell, J. T., Eden, L., \& Miller, S. R. (2012). Multinationals and corporate social responsibility in host countries: Does distance matter? Journal of International Business Studies, 43(1), 84-106.

Chung, H. M., \& Dahms, S. (2018). Ownership strategy and foreign affiliate performance in multinational family business groups: A double-edged sword. Journal of International Management, 24(4), 303-316.

Csomós, G. (2017). Cities as command and control centres of the world economy: An empirical analysis, 2006-2015. Bulletin of Geography. Socio-economic Series, 38(38), 7-26.

Dahms, S. (2017a). A fuzzy set analysis of foreign-owned subsidiary performance: Insights from East Asia. Journal of Asia-Pacific Business, 18(4), 224-241.

Dahms, S. (2017b). Determinants of foreign-owned subsidiary performance in emerging economies. Management Research Review, 40(6), 626-647.

Dahms, S. (2018). The effects of networks and autonomy on foreign-owned subsidiary competence development in Taiwan. International Journal of Emerging Markets, 13(6), 1615-1634.

Dahms, S. (2019a). Power, CSR strategy, and performance in foreign-owned subsidiaries. Canadian Journal of Administrative Sciences/Revue Canadienne des Sciences de l'Administration. https://doi.org/10.1002/ cjas. 1539 
Dahms, S. (2019b). The influence of competences and institutions on the international market orientation in foreign-owned subsidiaries. European Journal of International Management. 13(3), 354-380.

Dahms, S. (2019c). Foreign-owned subsidiary knowledge sourcing: The role of location and expatriates. Journal of Business Research, 105, 178-188.

Dahms, S., Cabrilo, S., \& Kingkaew, S. (2020). The role of networks, competencies, and IT advancement in innovation performance of foreign-owned subsidiaries. Industrial Marketing Management. https://doi. org/10.1016/j.indmarman.2020.03.013

Dahms, S., \& Kingkaew, S. (2019). A configurational perspective on subsidiary top management team national diversity and performance. Personnel Review, 48(6), 1507-1529.

Delany, E. (2000). Strategic development of the multinational subsidiary through subsidiary initiative-taking. Long Range Planning, 33(2), 220-244.

Doh, J., Husted, B. W., Matten, D., \& Santoro, M. (2010). Ahoy there! Toward greater congruence and synergy between international business and business ethics theory and research. Business Ethics Quarterly, 20(03), 481-502.

Donaldson, T., \& Dunfee, T. W. (1994). Toward a unified conception of business ethics: Integrative social contracts theory. Academy of Management Review, 19(2), 252-284.

Fiss, P. C. (2007). A set-theoretic approach to organizational configurations. Academy of Management Review, 32(4), 1180-1198.

Fornell, C., \& Larcker, D. F. (1981). Evaluating structural equation models with unobservable variables and measurement error. Journal of Marketing Research, 18(1) 39-50.

Frynas, J. G., \& Yamahaki, C. (2016). Corporate social responsibility: Review and roadmap of theoretical perspectives. Business Ethics: A European Review, 25(3), 258-285.

Gammelgaard, J., McDonald, F., Stephan, A., Tüselmann, H., \& Dörrenbächer, C. (2012). The impact of increases in subsidiary autonomy and network relationships on performance. International Business Review, 21(6), 1158-1172.

Gaur, A. S., Delios, A., \& Singh, K. (2007). Institutional environments, staffing strategies, and subsidiary performance. Journal of Management, 33(4), 611-636.

Ghoshal, S., \& Bartlett, C. A. (1990). The multinational corporation as an interorganizational network. Academy of management review, 15(4), 603-626.

Hah, K., \& Freeman, S. (2014). Multinational enterprise subsidiaries and their CSR: A conceptual framework of the management of CSR in smaller emerging economies. Journal of Business Ethics, 122(1), 125-136.
Hair, J. F., Sarstedt, M., Pieper, T. M., \& Ringle, C. M. (2012). The use of partial least squares structural equation modelling in strategic management research: A review of past practices and recommendations for future applications. Long Range Planning, 45(5), 320-340.

Hamel, G., \& Prahalad, C. K. (1996). Competing for the future. Harvard Business Press.

Hoskisson, R. E., Wright, M., Filatotchev, I., \& Peng, M. W. (2013). Emerging multinationals from mid-range economies: The influence of institutions and factor markets. Journal of Management Studies, 50(7), 1295 1321.

Husted, B. W., \& Allen, D. B. (2006). Corporate social responsibility in the multinational enterprise: Strategic and institutional approaches. Journal of International Business Studies, 37(6), 838-849.

Jamali, D. (2010). The CSR of MNC subsidiaries in developing countries: Global, local, substantive or diluted? Journal of Business Ethics, 93(2), 181-200.

Jamali, D., \& Karam, C. (2016). Corporate social responsibility in developing countries as an emerging field of study. International Journal of Management Reviews. doi: 10.1111/ijmr.12112

Jaén, M. H., Auletta, N., Celli, J. B., \& Pocaterra, M. (2018). Bibliometric analysis of indexed research on corporate social responsibility in Latin America (2000-2017). Academia Revista Latinoamericana de Administración, 31(1), 105-135.

John, G., \& Weitz, B. A. (1988). Forward integration into distribution: An empirical test of transaction cost analysis. Journal of Law, Economics, \& Organization, 4(2), 337-355.

Kingkaew, S., \& Dahms, S. (2018). Headquarters value added and subsidiary performance: Insights from Thailand. Review of International Business and Strategy, 28(2), 150-168.

Kock, N. (2014). Stable P value calculation methods in PLS-SEM. ScriptWarp Systems.

Kock, N. (2011). Using WarpPLS in e-Collaboration studies: Descriptive statistics, settings. International Journal of E-Collaboration (IJeC), 7(2), 1-18.

Kogut, B., \& Singh, H. (1988). The effect of national culture on the choice of entry mode. Journal of International business Studies, 19(3), 411-432.

Monteiro, L. F., Arvidsson, N., \& Birkinshaw, J. (2008). Knowledge flows within multinational corporations: Explaining subsidiary isolation and its performance implications. Organization Science, 19(1), 90-107.

Moore, K. J. (2001). A strategy for subsidiaries: Centres of excellences to build subsidiary specific advantages. MIR: Management International Review, 41(3), 275-290. 
Muller, A. (2006). Global versus local CSR strategies. European Management Journal, 24(2), 189-198.

Neter J., Wasserman, W., \& Kutner, M. (1985). Applied linear statistical models. Irwin Press.

Nguyen, Q. T., \& Rugman, A. M. (2015). Multinational subsidiary sales and performance in South East Asia. International Business Review, 24(1), 115-123.

Nunnally, J. (1978). Psychometric theory. McGraw Hill.

Park, B. I., \& Ghauri, P. N. (2015). Determinants influencing CSR practices in small and medium sized MNE subsidiaries: A stakeholder perspective. Journal of World Business, 50(1), 192-204.

Podsakoff, P. M., \& Organ, D. W. (1986). Self-reports in organizational research: Problems and prospects. Journal of Management, 12(4), 531-544.

Porter, M. E. (1985). Competitive advantage: Creating and sustaining superior performance. FreePress.

Prado, A. M., \& Woodside, A. G. (2015). Deepening understanding of certification adoption and non-adoption of international-supplier ethical standards. Journal of Business Ethics, 132(1), 105-125.

Ragin, C. C. (2008). Redesigning social inquiry: Fuzzy sets and beyond. University of Chicago Press.

Rathert, N. (2016). Strategies of legitimation: MNEs and the adoption of CSR in response to host-country institutions. Journal of International Business Studies, 47(7), 858-879.

Reimann, F., Ehrgott, M., Kaufmann, L., \& Carter, C. R. (2012). Local stakeholders and local legitimacy: MNEs' social strategies in emerging economies. Journal of International Management, 18(1), 1-17.

Reimann, F., Rauer, J., \& Kaufmann, L. (2015). MNE subsidiaries' strategic commitment to CSR in emerging economies: The role of administrative distance, subsidiary size, and experience in the host country. Journal of Business Ethics, 132(4), 845-857.

Rugman, A. M., \& D'Cruz, J. R. (2003). Multinationals as flagship firms: Regional business networks. Oxford University Press.

Rugman, A. M., \& Verbeke, A. (2001). Subsidiary-specific advantages in multinational enterprises. Strategic Management Journal, 22(3), 237-250.

Rugman, A. M., \& Verbeke, A. (2003). Extending the theory of the multinational enterprise: Internalization and strategic management perspectives. Journal of International Business Studies, 34(2), 125-137.

Sapouna, P., Manolopoulos, D., \& Dimitratos, P. (2016). How do MNC R\&D laboratory roles affect employee international assignments? Management International Review, 56(5), 759-779.
Schneider, C. Q., \& Wagemann, C. (2010). Standards of good practice in qualitative comparative analysis (QCA) and fuzzy-sets. Comparative Sociology, 9(3), 397-418.

Sethi, S. P. (1990). An analytical framework for making cross cultural comparisons of business responses to social pressures: The case of the United States and Japan. In L. E. Preston (Ed), International and comparative corporation and society research (pp. 29-56). Jai Press Inc.

Shapiro, D. M., Vecino, C., \& Li, J. (2018). Exploring China's state-led FDI model: Evidence from the extractive sectors in Latin America. Asia Pacific Journal of Management, 35(1), 11-37.

Shirodkar, V., Beddewela, E., \& Richter, U. H. (2016). Firm-level determinants of political CSR in emerging economies: Evidence from India. Journal of Business Ethics, 148(3), 673-688.

Statista. (2020). Plecher, H. Share of economic sectors in the global gross domestic product from 2007 to 2017, Available at https://www.statista.com/statistics/256563/share-of-economic-sectors-in-the-global-gross-domestic-product/\#statisticContainer (Accessed April 3 2020).

Tatoglu, E., Bayraktar, E., Sahadev, S., Demirbag, M., \& Glaister, K. W. (2014). Determinants of voluntary environmental management practices by MNE subsidiaries. Journal of World Business, 49(4), 536-548.

US State Department. (2013). Investment climate statement, bureau of economic and business affairs, available at www.state.gov/e/eb/rls/othr/ics/2013/204742. htm (accessed 19 June 2017).

Verbeke, A., Kano, L., \& Yuan, W. (2016). Inside the regional multinationals: A new value chain perspective on subsidiary capabilities. International Business Review, 25(3), 785-793.

Wetzels, M., Odekerken-Schröder, G., \& Van Oppen, C. (2009). Using PLS path modelling for assessing hierarchical construct models: Guidelines and empirical illustration. MIS Qquarterly, 33(1), 177-195.

Woodside, A. G. (2013). Moving beyond multiple regression analysis to algorithms: Calling for adoption of a paradigm shift from symmetric to asymmetric thinking in data analysis and crafting theory. Journal of Business Research, 66(4), 463-472

World Bank. (2011). World Bank's enterprise survey understanding the questionnaire. http://www.enterprisesurveys.org/ /media/GIAWB/EnterpriseSurveys/ Documents/Methodology/Questionnaire-Manual.pdf (accessed 19 june 2017). 
Yang, X., \& Rivers, C. (2009). Antecedents of CSR practices in MNCs' subsidiaries: A stakeholder and institutional perspective. Journal of Business Ethics, 86, 155-169.

Yin, J., \& Jamali, D. (2016). Strategic corporate social responsibility of multinational companies' subsidiaries in emerging markets: Evidence from China. Long Range Planning, 49(5), 541-558.
Zaheer, S. (1995). Overcoming the liability of foreignness. Academy of Management Journal, 38(2), 341-363. 